TECHNICAL PAPER

\section{JOURNAL OF THE SOUTH AFRICAN} INSTITUTION OF CIVIL ENGINEERING ISSN 1021-2019

Vol 61 No 4, December 2019, Pages 42-49, Paper 0337

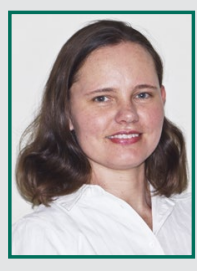

DR ISOBEL BRINK is a senior lecturer in the field of water quality within the Department of Civil Engineering at Stellenbosch University. She has published works on various topics related to water quality, including stormwater runoff quality, stream solute modelling and small-scale Point of Use systems for potable water improvement. Currently, her research is focused on the use of green infrastructure towards stormwater quality improvement.

Contact details:

Department of Civil Engineering

Stellenbosch University

Private Bag X1

Matieland 7602

South Africa

T: +27218084195

E: icbrink@sun.ac.za

Small-scale dispersed Green Infrastructure a fitting civil engineering solution to stormwater quality improvement?

I C Brink

Stormwater quality has been researched for decades, but design innovation has stagnated. The design engineer is commonly faced with a large array of design options, each with complex mechanisms requiring specialised knowledge, often in fields that do not form part of civil engineering training. Adequately combining and establishing the necessary knowledge from these fields requires a practically valid design focus. An investigation into whether small-scale dispersed Green Infrastructure (Gl) can serve as such a focus for stormwater runoff quality improvement was performed. It was found that small-scale GI application provides a dispersed and passive treatment response to the spatially diffuse nature of stormwater runoff. This technology has comparable efficiencies to other traditional stormwater structures, with the added advantage of being incorporable into existing infrastructure. It is, however, not without its share of disadvantages and knowledge gaps. Future research into many aspects ranging from data collection to implementation is warranted.

\section{INTRODUCTION}

Stormwater quality is currently seen as the leading remaining cause of poor water quality in natural systems (USEPA 2016). Whereas technologies towards treatment and management of point sources of water pollution such as domestic and industrial sewage have been thoroughly researched and developed in the past century, few practical technologies have been developed for the treatment of stormwater runoff. Although international attention has been given to this topic since the 1960s, research and practical design guideline development in this area have stagnated. Innovation in this field is slowing down, with few designs based on quantitative theoretical bases. Instead, prescriptive methods such as the USA BMP design methods, whereby drainage structure geometry is prescribed, are commonly used (Fassman 2012; Brink 2016).

Literature on stormwater management, both for quantity and quality, was published decades ago internationally, as well as in South Africa. For example, Wanielista (1979) included a chapter on water quality responses to nonpoint sources with case studies more than 30 years ago. In South Africa, more than 15 years ago, Schoeman et al (2001) identified the need for managing the quality of urban stormwater runoff to prevent the spread of diseases, control the costs of water purification and reduce threats to the aquatic environment. In 2003, Quibell et al stated that in South Africa “... nonpoint source pollution has not been effectively addressed on an extensive scale." Although such texts identified the problem of stormwater runoff quality years ago, practical engineering design guidelines have not emerged. In 2006 the American Society of Civil Engineers (ASCE 2006) stated that "... the control of water quality in urban runoff is in its technical infancy." Today, another decade later, not much has changed.

South Africa suffers from the same major impediments regarding the development of practical design methodologies as many other countries do. Most prominent amongst these are difficulties with obtaining data on pollutant concentrations and flows, as well as a large selection of published design methods with little or no reference to their theoretical bases. For example, Schoeman et al (2001) performed a review of South African urban runoff studies and found that, although more than 50 studies had been done locally from the 
late 1980s, very few contributed meaningful water quality data coupled with flow data. Additionally, standard and comparable sets of water quality constituents were not measured across case studies. Costs associated with chemical analysis were mentioned as a main factor in the paucity of measured data.

The paucity of pollutant data by itself is not the only impediment to stormwater quality improvement solutions. Design data must also be obtained with a specific design methodology in mind. Adaptation of stormwater quantity control structures to serve as water quality improvement structures leaves the designer with a very large choice of structures, each with its own largely unexplained mechanisms of water quality improvement. Each mechanism of each structure requires specialised knowledge. Basins function with highly complex sedimentation processes in highly varying flow fields during storm events; wetlands have bio-removal and chemical speciation as an addition to sedimentation; swales include filtration and sorption, as well as sedimentation, again with highly varying parameters such as flows, bottom roughness, etc. These complexities in removal mechanisms, brought by high variation in structure physics, are difficult to work with. The result has been a large body of prescriptive methods, as well as some more involved methods that utilise standard engineering concepts but do not address removal mechanism complexities or data acquisition difficulties, including the time, manpower and costs involved with data gathering over a sprawling urban area over a significant period of time.

Stormwater design approaches that include water quality design considerations abound internationally. These include the United States Environmental Protection Agency (USEPA) Best Management Practice (BMP), the Australian and South African Water Sensitive Urban Design (WSUD) and the United Kingdom Sustainable Drainage Systems (SuDS) approaches. The USEPA website, for example, lists design manuals for a large number of states independently. Such manuals are often substantial and contain prescriptive qualitative recommendations. Specific and scientifically based guidelines are, however, lacking. For example, the New York State Stormwater Management Design Manual (Centre for Watershed Protection 2010) only states that rain-gardens have pollutant treatment benefits. It is also typical to find guidelines that include phrases like "moderate" or "high" pollutant removal for specific structures such as swales and ponds (e.g. ASCE 2006; Wisconsin Department of Natural Resources 2003) or even exact stated percentage removals such as $80 \%$ TSS removal for various structures (Wisconsin Department of Natural Resources 2003), or, for example, $49 \%$ Total Phosphorus removal for Wetlands (SEMCOG 2008). The design engineer, however, needs more detailed methods and information that include the quantities and types of pollutants removed, the mechanisms of removal as part of mathematical models, types of plants to implement, etc.

Published prescriptive methods are common and often include prescriptive design suggestions such as percentage plant coverage and specified side slope gradients (ASCE 2006; Wisconsin Department of Natural Resources 2003). For example, the ASCE (2006) Standard Guidelines for Design of Urban Stormwater Systems describe swales as planted shallow trenches with side slopes flatter than 3:1 and specify that retention ponds should have plants covering $30 \%$ of the pond area. In cases where such methodologies do not provide an explanation of the reasoning behind the choice of such exact values it can be questioned whether they can be applied as a general standard in different situations.

The generalised use of other, seemingly more involved design methods may also be questioned. For example, some methods use the Water Quality Volume parameter to design for water quality improvement (SEMCOG 2008). In these procedures, a Water Quality Volume is catered for in a design and the designer is thereby satisfied that a certain percentage pollutant removal will occur in the structure. However, the choice of Water Quality Volume itself is arbitrary, and a mechanism of calculation involving a range of parameter concentrations and flows may be more scientifically justifiable. Also common to more involved methods is a requirement for difficultto-measure parameters. For example, the ASCE (2006) advises that swales be designed using equations for open channel flow with a "... roughness coefficient suitably adjusted for grass or vegetation.” Data towards such requirements is difficult, if not impossible, for the design engineer to find in a project where the time allowed for design for environmental considerations of the project is based on the amount of money the design company will earn. This is typically relatively low for small stormwater control structures.

In South Africa, stormwater quality improvement has recently been revisited. There is currently a movement towards the acceptance of the Water Sensitive Urban Design (WSUD) philosophy. Within this, Sustainable Drainage Systems (SuDS) form the stormwater management component (Armitage et al 2013c). This philosophy has many aspects, but has been specifically defined by the authors of the "Water Sensitive Urban Design (WSUD) for South Africa - Framework and Guidelines" (Armitage et al 2013b) as designing the urban landscape with water sensitivity in mind. This framework provides broad philosophical guidance, but its aim is not yet to provide design specifics. In line with this, the SuDS component focuses on stormwater management rather than on specific design guidelines (Armitage et al 2013c).

Although current design approaches do not seem to have strong theoretical bases, they are in keeping with successful historical general trends in water quality design development. The activated sludge system, for example, was successfully used long before informative mathematical models were developed towards its optimisation (Mogens et al 2008). It is, however, time to move away from theoretically unsubstantiated design recommendations to scientifically based practical design methodologies.

The next step towards a practical implementation of a stormwater treatment philosophy in South Africa is to ascertain where research and development energy should be spent. Quibell et al (2003) state that, although South African law makes provision for protection of natural water sources, implementation is constrained by a lack of human and financial resources. Therefore, they argue that only through use of limited resources to best effect can the goals of the legislation be met.

For the design engineer to have confidence in a well-understood stormwater structure design method for water quality control where pollutant removals can be predicted accurately, he/she requires not only a valid set of data, but also a practical design focus. The use of Green Infrastructure (GI) for treatment of stormwater is gaining recognition. For example, the United States Environmental Protection Agency (USEPA) promotes GI as an ecological way to manage stormwater through promoting on-site treatment as a 
way to include natural plant-based systems in the urban environment (Yang et al 2015). In some USA states, GI application is even mandated by water regulators as part of new urban development projects (Anderson et al 2016), and is otherwise gaining much ground internationally (Geberemarium 2017). For example, a variety of GI systems have been implemented in New York City from as far back as the 1990s and the city released its Green Infrastructure Plan in 2010 already (UN Water 2018). The focus on GI as a practical design solution for stormwater quality improvement, one on which scarce development and research resources can be spent, is further investigated here. This paper therefore contains the results of an investigation into whether small-scale dispersed Green Infrastructure (GI) is a valid design and research focus area for stormwater quality improvement in terms of relative pollutant removal efficiencies, as well as practical considerations towards implementation.

\section{WHY SMALL-SCALE DISPERSED GREEN INFRASTRUCTURE (GI)?}

The definition of GI varies with different texts. A central precept across literature is the use of vegetated infrastructure to deliver desired services (Fletcher et al 2015). A particularly insightful definition is provided by the US Watershed Management Group (2012) who defines GI as “... constructed features that use living, natural systems to provide environmental services, such as capturing, cleaning and infiltrating stormwater; creating wildlife habitat; shading and cooling streets and buildings; and calming traffic." This definition highlights secondary benefits, as well as the primary benefit of stormwater quality improvement.

Commonly used stormwater quality control structures that also have the characteristics of GI, as defined (natural features, interconnected, etc) are swales (planted infiltration ditches), filter strips (planted areas over which stormwater can flow), planted retention (wet detention) ponds and artificial wetlands (ASCE 2006). Small-scale systems typically do not require additional land and can be incorporated within existing infrastructure boundaries, e.g. at roadsides, within household plot boundaries, etc. Therefore, retention ponds and wetlands are not considered to be small-scale GI. Other small-scale GI structures include bio-retention structures (water is captured and allowed to filter into a planted area with underdrains) and green roofs (roof areas utilised for planting and landscaping) (USEPA 2009; 2012; 2014).

The response to stormwater quality improvement must fit the problem logistics. Stormwater runoff has been described as "diffuse" in many texts. This single word aptly highlights the main problem with stormwater quality treatment. Stormwater is spread out, not concentrated. Conventional water treatment infrastructure, such as used in potable water and sewage treatment, have a single inflow point. All water is collected in a network and conveyed to treatment plants, which can then be operated and maintained cost-effectively. In the case of stormwater, the situation is very different. Actively treating a myriad of stormwater outflows into streams, rivers and oceans is a logistic dilemma, because re-routing all stormwater pipelines to treatment plants will involve great cost and effort. An alternative to such active treatment is passive treatment, i.e. systems that do not require regular active input for correct functioning. GI involves passive natural systems that can be dispersed across urban areas, and may therefore be a fitting response to the dispersed nature of stormwater runoff.

In addition to active/passive treatment response, an important physical constraint to infrastructure implementation is land availability. Municipalities are responsible for implementation of stormwater quality control infrastructure in urban areas where public land either has commercial value or is highly limited at stormwater outflow points. The response must therefore be small-scale to enable implementation at a multitude of points where space is limited. Small-scale GI, such as vegetated filter strips, bio-retention structure facilities and swales, fit this requirement.

\section{SMALL-SCALE GI MASS REMOVAL EFFICIENCIES}

An investigation into solids mass removal fractions for a range of water quality control structures was done with data obtained from the International Stormwater BMP Database (2016). Masses and negative removals were specifically included to augment a lack of emphasis in published literature in this area. The case studies all originate from the United States of America. Although they are therefore geographically displaced from the South
African setting, they originate from urban settings in another industrialised country, supporting the use of the investigative outcomes towards informing future research in South Africa.

Total Suspended Solids (TSS) and Total Dissolved Solids (TDS) comprise all stormwater pollutants. Further refinement into constituent pollutants was not deemed necessary at this stage, but should form part of future research. Structures were chosen according to availability of both water quality data and storm volume data. These were:

1. Detention basins, defined as basins with no significant permanent pool between storm events

2. Retention ponds, defined as basins with a permanent pool of water

3. Bio-filter grass strips, defined as vegetated areas that accept sheet flow

4. Bio-filter grass swales, defined as shallow grass-lined channels with little bottom width

5. Wetland basins or channels, defined as structures with dense wetland vegetation (more than 50\% in the case of a basin)

6. Bio-retention structures, defined as shallow, soil-engineered, landscaped areas with or without underdrain systems.

(Definitions obtained from Wright Water Engineers Inc and Geosyntech Consultants Inc 2016)

Out of these structural types bio-filter grass strips, grass swales and bio-retention structures were considered to be examples of small-scale GI.

Water quality, flow and monitoring station data was downloaded in raw form. TSS and TDS flow-weighted composite Event Mean Concentration (EMC) data was extracted and matched with corresponding flow volumes per storm event. EMC data was multiplied with structured in and out storm volumes to determine estimated TSS and TDS masses. Positive and negative (outflow masses greater than inflow masses per storm event) fraction removals were calculated. The fraction removal calculation was as follows:

$\begin{aligned} & \text { Mass Fraction } \\ & \text { Removed }\end{aligned}=\frac{E M C_{\text {in }} V_{\text {in }}-E M C_{\text {out }} V_{\text {out }}}{E M C_{\text {in }} V_{\text {in }}}(1)$

Where EMC is the Event Mean Concentration (in or out of the structure) per storm event and $\mathrm{V}$ is the storm volume (in or out of the structure) per storm event. 
Statistics for the positive results, where outflow masses were greater than inflow masses per storm event, as well as the percentage of negative removal events, are shown in Figures 1 and 2. Fassman (2012) performed a similar study with data from the same database pre-2012, but focused on concentrations rather than masses. The use of the mass fraction has the advantage of allowing direct inflow and outflow parameter comparisons without the influence of unaccounted volumes that may have entered or exited the structure, such as base flow, seepage or overland flow, which influence concentration measurements.

From Figure 1 it can be seen that the bio-filter grass strips and retention ponds had the highest median TSS mass removal efficiencies ( $>0.9)$. These were closely followed by bio-retention structures and biofilter grass swales $(>0.75)$. There were large discrepancies in sample sizes available for the analysis, and the high bio-filter grassstrip removal result must be accepted with caution with a sample size of only $23(\mathrm{~N})$. Positive mass fraction removal medians were below 0.75 for the detention basins (0.73) and wetlands (0.58).

The bio-retention structure and swale results were comparable with those found in literature. Fassman (2012) found, based on effluent concentrations, that bioretention structures and grass swales tended to provide better effluent TSS concentrations. Bio-retention structures have been shown to be very efficient at stormwater pollutant removals. Percentage removal efficiencies have been over $80 \%$ for the metals lead, copper and zinc, as well as TSS (TRCS \& CVC 2010; Xiao \& McPherson 2011, Anderson et al 2016). Nutrient removals of phosphorus and nitrogen, however, have typically been low or even negative, possibly due to fertilizer application (TRCA \& CVC 2010; USEPA 2009). Yang et al (2015) investigated bio-swales for metals, nutrients and TSS removal efficiency. They found that the bio-swale system outperformed the traditional detention basin system in their study with more than $80 \%$ difference in removals of all pollutants.

Positive fraction removal ranges were very high, with most structure types showing a possibility of achieving nearly no (0) removals as well as near-perfect (1) removals of all inflow masses. An exception was the bio-filter grass strips with a minimum positive fraction removal of 0.31 . Data spread was highest for the structures with the worst removals, namely detention

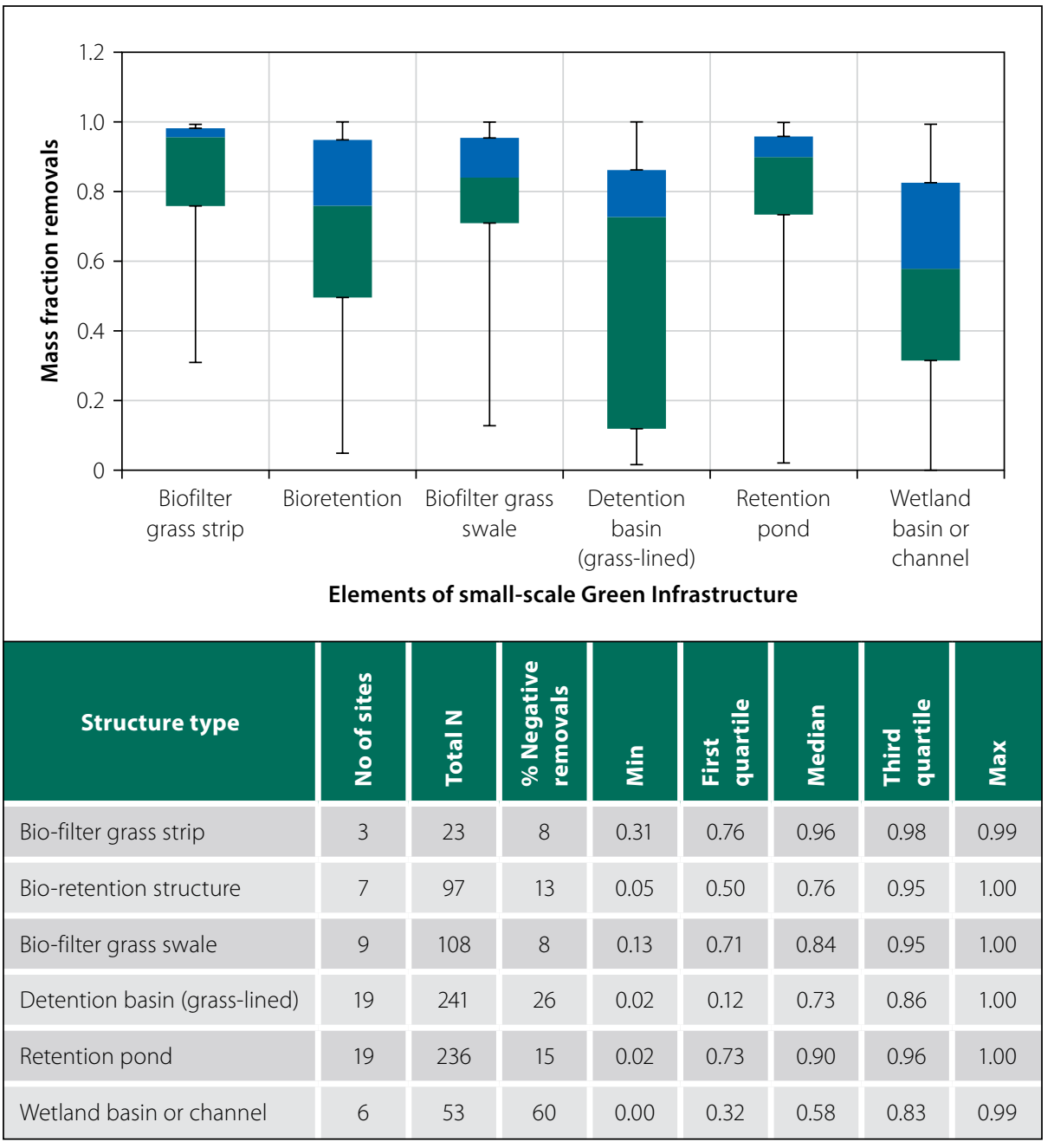

Figure 1 TSS positive fraction removals - box plots and data summary

basins and wetlands (IQR > 0.5) and lowest for the best-performing structures, namely bio-filter grass strips and swales as well as retention ponds (IQR $<0.25)$. This indicates that the worst-performing structures had highly variable positive mass removal efficiencies. This may further indicate highly diverse design and operating conditions for these structures.

The percentage of storm events that resulted in negative fraction removals, i.e. where outflow masses were greater than inflow masses, showed that the worstperforming structures in terms of positive fraction removals also performed worst in terms of negative removals. Detention basins had negative mass removals during $26 \%$ of the storm events measured. Wetlands had negative mass removals during a notable $60 \%$ of storm events measured. The best-performing structures also had negative removals with $8 \%$ for biofilter grass strips and swales and 15\% for retention ponds. This indicates that design of these structures should include thought towards preventing re-suspension of previously captured solids during successive storm events.
Like for TSS, the best-performing structures in terms of TDS median removals were bio-filter grass strips (0.79) and retention ponds (0.93) (Figure 2). All other structures had relatively poor median removals ( 0.4). All sample sizes $(\mathrm{N})$ were relatively small when compared to TSS with the largest sample size for detention ponds $(\mathrm{N}=70)$. Results should therefore be read with caution.

Maximum positive fraction removal ranges were once again very high, with most structure types showing a possibility of achieving nearly no (0) removals as well as near-perfect (1) removals of all inflow masses. Data spread was similar for all structures $(0.38>\mathrm{IQR}<0.6)$ (refer to Figure 2). This once again indicates highly variable positive mass removal efficiencies, and highly diverse design and operational settings for all structures.

The percentage of storm events that resulted in negative fraction removals showed different trends than were found for TSS. The best-performing structure type in terms of median removals, namely retention ponds, had the highest amount of negative removals (80\%). Most other 
structures also had mainly negative removals (>50\%). The exception was bio-filter grass swales with $15 \%$ negative removal events. This indicates that, though the structures all had the capacity to remove TDS, most contributed in some way to TDS in their effluents. The reasons for this are unknown at this stage.

These results illustrate that smallscale GI structures (bio-filter grass strips, bio-filter grass swales and bio-retention structures) had comparable efficiencies to other stormwater structure types and generally performed better than detention basins and wetlands. Retention ponds had very high median removals, but also had higher negative removal percentages than any small-scale system. It was therefore concluded that small-scale GI structures could have competitive efficiencies when compared to other stormwater quality improvement structures.

Additional to the results above, green roofs were not evaluated due to lack of data, but have been shown in literature to give percentage differences compared to conventional roofs of $89 \%$ for TSS, $-248 \%$ for phosphorus, $91 \%$ for nitrates, $69 \%$ for aluminium, $69 \%$ for zinc, $86 \%$ for copper and $11 \%$ for e-coli. The increase in phosphorus was attributed to fertilisers and leaching (TRCA \& CVC 2010).

\section{GI KNOWLEDGE GAPS}

Substantial work towards GI implementation has been done and can form a foundation for further improvements in design. In South Africa, the South African Guidelines for Sustainable Drainage Systems

(Armitage et al 2013b), recently made available, provide guidance towards quantity design considerations such as runoff estimation and infiltration design. Referrals towards case studies and documented removal capacities of different technologies including green roofs, bio-retention structures, filter strips, swales and wetlands are given. Additionally, a number of GI projects have recently been implemented in the USA and may be used as examples of good design practices. The reader is referred to the EPA Green Infrastructure technical assistance program projects (USEPA 2009; 2012; 2014).

Although much work on various design guidelines has been done, further research into specific infrastructure design details is required. GI performance has been substantially researched and documented;

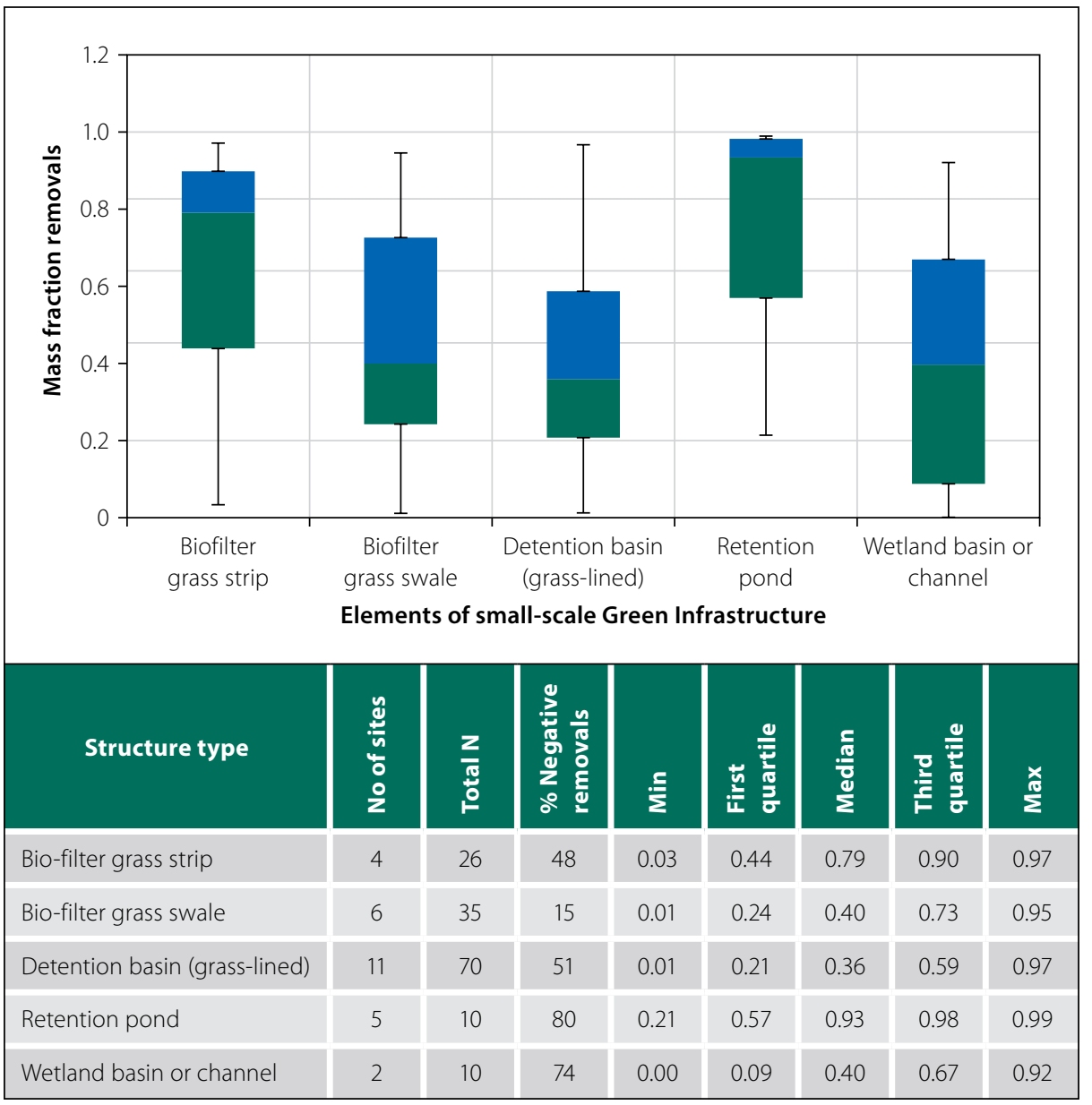

Figure $\mathbf{2}$ TDS positive fraction removals - box plots and data summary

however, this knowledge has not been adequately linked to theoretical explanations of removal mechanisms. Design guidelines often contain broad statements about pollutant removal abilities. Statements such as " $80 \%$ removal of TSS" and " $50 \%$ removal of total Phosphorus” (Wisconsin Department of Natural Resources 2003) are included with no reference to the source of the information and little theoretical support for the statements made. It is interesting to note that many design guides have the aim to reduce TSS in stormwater runoff by $80 \%$ and the stated efficiencies of the prescribed stormwater control structures are also exactly $80 \%$ TSS removal. This does not engender much confidence in the theoretical base for the stated efficiencies. Additionally, design of GI structures is not only lacking in removal efficiency knowledge, but also in insight into volume prediction. For example, a recent attempt at finding scientifically based and useable design insights for bio-retention structures have yielded limited results (Davis et al 2012).

In South Africa, Burke \& Mayer (2009) identified, through consultation with various municipalities, the development of user-friendly stormwater selection, design and management tools as a top research need. This is a good end goal, but it is necessary to establish a scientific understanding of pollutant mechanisms first. GI design methodologies do exist (TRCA \& CVC 2010; HR Wallingford Ltd 2017; USEPA n.d.), but are lacking in depth. For example, Cording et al (2017) state that, although roadside bio-retention structure systems are becoming increasingly popular, installation of such systems is outpacing research on the subject.

GI system design is complex and requires not only typical engineering hydrology knowledge, but also insights into the functioning of natural elements. Such knowledge is not usually included in the typical training of civil engineers. Conversely, mathematically based approaches to infrastructure design are not usually included in the typical training of environmental scientists. Nevertheless, it is exactly such an amalgamation of knowledge from both fields that is required for the creation of a design science for GI. The contribution of plants, soil filtration and micro-organisms to pollutant removals has not been greatly explored by engineers. Although plant uptake and filtration are often seen as major removal 
mechanisms, there are also indications that bacteria can be responsible for significant amounts of pollutant uptake. For example, Endreny et al (2012) found reduction in nitrate and zinc concentrations in a bio-retention structure bacterial column study, while conversely, phosphates increased in some cases. Application of GI as an engineering solution to stormwater quality improvement therefore requires extensive research into species selection, pollutant uptake mechanisms and implementation specifically towards stormwater quality improvement.

Some research into species selection is under way in South Africa. Milandri et al (2012) performed a study to assess the nutrient removal capabilities of nine locally occurring plant species in Cape Town, eight of which were indigenous. Compared to a soil-only control, they found that most species were efficient at $\mathrm{PO}_{4}{ }^{3-}$ and $\mathrm{NH}_{3}$ removals, achieving removal rates of over $90 \%$ in some cases. The soil-only controls were on average only $70 \%$ efficient for these parameters. Additionally, the soil-only controls removed on average $22 \%$ of $\mathrm{NO}_{3}{ }^{-}$ while removals up to $88 \%$ were found with certain plant species. Identification of the most appropriate species to use for pollutant removals in urban applications, modelling of removal mechanisms by plants, soil and micro-organisms within the system and determination of practical installation aspects require further research. This has also been identified by other researchers working in this area (Yang et al 2015).

In addition to the lack of understanding of pollutant removal mechanisms, data acquisition remains an impediment to design. Any design requires input, but pollutants in runoff are difficult to estimate without access to site-specific data, which is expensive and time-consuming to acquire. In South Africa, Quibell et al (2003) developed a non-point source assessment guide to aid designers in the selection of appropriate modelling tools. The main focus of the work was, however, on sediment runoff in agricultural areas and all models discussed required in-field knowledge of parameters, which is difficult to obtain and can be highly variable or qualitative. More research into this area is warranted.

\section{GENERAL ADVANTAGES AND DISADVANTAGES COMPARED}

A key advantage of GI as a solution

to stormwater quality is that it can be integrated as a source control measure. This enables a dispersed response to the dispersed nature of stormwater. The ASCE (2006) state that source control is difficult to establish, because home owners are unlikely to limit application of pollutants such as fertilisers to their gardens. It is, however, possible to persuade not only home owners, but also municipalities that manage public open spaces, to consider site control measures such as application of water purifiers (specific plant types) and infiltration systems to their planted and open areas.

An apparent major disadvantage of GI is that it, as the name implies, includes living entities, most notably plants. Plants may grow prolifically in the right conditions. Regular maintenance of such infrastructure will therefore be required and may be seen as a disadvantage by municipalities or private owners. For example, Armitage et al (2013a) noted that the Century City wetlands (Cape Town) seemed to be able to mitigate stormwater quality, but required much maintenance, including annual dredging, fish removal, bi-weekly invasive plant and algae removal and regular bird faeces removal. A counter argument is that the labour-intensive maintenance requirement could be used in public job creation initiatives. An additional disadvantage is that plants require water, which is a scarce resource in South Africa. This requirement may be mitigated by planting indigenous species that are adapted to the local rainfall patterns.

A wide range of auxiliary advantages is often touted for Green Infrastructure. These include protection of watersheds, improvement of outdoor experiences, and improvement of air quality (USEPA 2012), carbon storage and even climate change impact reduction (HR Wallingford Ltd. 2017). Not much direct evidence is provided to back up such statements. This wide focus can, however, be a disadvantage for design. It may distract from specific application towards the purpose of stormwater quality improvement. The application of the concept of GI in civil engineering towards the improvement of stormwater quality should have only one goal, namely the improvement of stormwater quality. The design engineer must not be distracted by this broad range of GI benefits, which may be turned into objectives by the human mind. In other words, including design thinking towards "air purification" or "climate change impact reduction" should be excluded from the stormwater quality application. These possible benefits can instead be included as secondary advantages.

Additional considerations include:

- Cost: The capital costs associated with Green Infrastructure are generally considered to be lower than conventional technologies, but may require more intensive maintenance (HR Wallingford Ltd. 2017; USEPA 2012). Conversely, specific applications such as green roofs may cause increased costs due to increased load carrying structural requirements, waterproofing, etc (TRCA \& CVC 2010).

- Public Safety: A possible concern with the planting of bushes and trees in public areas is that areas for crime are created. Conversely, public green areas can also be seen as having health benefits towards stress reduction. Kondo et al (2015) performed a study to ascertain the effects of green stormwater infrastructure on public safety over two years at sites in Philadelphia, USA, by relating crime (assaults, robberies, narcotics possession, etc) to areas with green stormwater infrastructure. No relationship was found for most crimes, including serious crimes (gun possession, assault, etc), or health indicators. Interestingly, the authors did find a reduction in narcotics possession in these spaces. Therefore, this study indicates little to no difference to the wellbeing, or lack thereof, for people who live close to green infrastructure spaces.

- Nutrient addition: Plants require nutrients such as phosphorus and nitrogen. These will need to be applied to new plant installations, probably as fertiliser, to ensure healthy plant growth. The very installation of GI may therefore add nutrients to the stormwater overflow. For example, EPA (USEPA 2009) found that green roofs from five sampled sites had more than $300 \%$ higher phosphorus in runoff than standard asphalt roofs, although the average value was still relatively low at $0.41 \mathrm{mg} / \ell$. Furthermore, bacteria may release phosphates from the soil medium. Endreny (2012) found increases in phosphorus concentrations in a bio-filter bacterial column study. This was attributed to phosphorus release during microbial decomposition of organic media.

- Stormwater runoff volume reductions: GI has been shown to not only reduce runoff volumes through infiltration, 
but also through evapotranspiration (Schoeman et al 2001; USEPA 2012).

- Improved biodiversity: A study by Kazemi et al (2011) in Melbourne, Australia, where nine bio-retention swales were studied in comparison to lawn and garden-type green spaces found a higher invertebrate species richness in the swales. This indicated that GI, by utilising a variety of vegetation, can be used to increase living spaces for indigenous plants and animals within urban environments.

- Nuisance: An increase in nuisance elements such as standing water and mosquitoes (TRCA \& CVC 2010) can, however, be mitigated through careful design.

\section{CONCLUSIONS}

Even though stormwater quality has been researched for decades, design innovation has stagnated. The design engineer is commonly faced with a large array of structure options, each with either prescriptive qualitative or more involved design methods that have difficult-toobtain parameters. Such design methods commonly have claims of percentage removals with seemingly little scientific base. This is a result of the application of simplified approaches to highly complex problems. Each mechanism of each structure requires specialised knowledge, often in fields that do not form part of civil engineering training. Knowledge of not only complex fluid dynamics, but also within the fields of botany (plant uptake, species selection), microbiology (bacterial uptake) and geology (soil interaction) is required. Adequately combining and establishing the necessary knowledge from these fields within a limited research and development resource context requires a practically valid design focus.

Small-scale dispersed Green Infrastructure (GI) was found to be a valid civil engineering approach to stormwater runoff quality improvement and can serve as a practical design focus point. Specifically, small-scale GI application provides a dispersed and passive treatment response to the spatially diffuse nature of stormwater runoff. This technology has comparable efficiencies to other traditional stormwater structures, with the added advantage of being incorporable into existing infrastructure (roadsides, private gardens, etc). Additionally, GI can be added as a technological focus within the South African WSUD framework.

Through a quantitative comparative investigation of removal efficiencies, smallscale dispersed GI elements (bio-filter grass strips, bio-filter grass swales and bio-retention structures) were compared to retention ponds, detention basins and wetlands in terms of median TSS and TDS mass removal efficiencies. It was found that, although retention ponds performed best overall for TSS median mass removals, the small-scale dispersed GI structures performed comparably well ( $>0.75$ median mass removals) and better than the detention basins and wetlands. TDS median mass removals were poor for all structures ( 0.4), except for bio-filter grass strips (0.79) and retention ponds (0.93). However, all structures, including retention ponds, showed negative removals for both TSS and TDS, indicating that materials may be washed out of these structures during large storm events. The results therefore showed that the small-scale GI structures had comparable efficiencies to other stormwater structure types and generally performed better than detention basins and wetlands, making them a viable alternative.

The concept of GI is not unusual for application to the field of water treatment. The fundamental use of natural systems to treat water is not new and has manifested in the activated sludge system for sewage treatment, algal ponds for effluent treatment and reed beds for various applications. Although all of these technologies are not specifically "green", they are natural and the leap in thinking towards using GI systems for stormwater treatment should not be great for the water-quality engineer. This technology is, however, not without its share of disadvantages and knowledge gaps. Much future research into many aspects, ranging from data collection to implementation, is warranted.

\section{REFERENCES}

ASCE (American Society of Civil Engineers) 2006. Standard guidelines for the design of urban stormwater systems. Reston, VA: ASCE,

Anderson, B S, Phillips, B M, Voorhees, J P, Siegler, K \& Tjeerdema, R 2016. Bioswales reduce contaminants associated with toxicity in urban stormwater. Environmental Toxicology and Chemistry, 35(12): 3124-3134.

Armitage, N, Vice, M, Fisher-Jeffes, L, Winter, K, Spiegel, A \& Dunstan, J 2013a. Alternative technology for stormwater management: Sustainable drainage systems - report and South African case studies. WRC Report No 1826/1/13. Pretoria: Water Research Commission.

Armitage, N, Vice, M, Fisher-Jeffes, L, Winter, K, Spiegel, A \& Dunstan, J 2013b. Water Sensitive Urban Design (WSUD) for South Africa - Framework and guidelines. WRC Report No TT588/14. Pretoria: Water Research Commission.

Armitage, N, Vice, M, Fisher-Jeffes, L, Carden, K, Winter, K, Naidoo, V, et al. 2013c. Alternative technology for stormwater management: The South African guidelines for sustainable drainage systems. WRC Report No TT558/13. Pretoria: Water Research Commission.

Brink, I C 2016. Design of stormwater ponds towards the reduction of metal toxins in surface waters that are utilised for South African primary food production. PhD Thesis, University of Stellenbosch. Burke, J \& Mayer, X 2009. Strategic guidance towards prioritising stormwater management research in human settlements. WRC Report No 1670/1/09. Pretoria: Water Research Commission.

Centre for Watershed Protection 2010. New York State stormwater management design manual. Albany, NY: Centre for Watershed Protection.

Cording, A, Hurley, S \& Whitney, D 2017. Monitoring methods and design for evaluating Bio-retention structure performance. Journal of Environmental Engineering, 143(12): 1-9.

Davis, A P, Traver, R G, Hunt, W F, Lee, R, Brown, R A \& Olszewski, J M 2012. Hydraulic performance of Bioretention structure storm-water control measures. Journal of Hydraulic Engineering, 17(5): 604-614.

Endreny, T, Burke, D J, Burchhardt, K M, Fabian, M W \& Kretzer, A M 2012. Bio-retention structure column study of bacteria community response to salt-enriched artificial stormwater. Journal of Environmental Quality, 41: 1951-1959.

Fassman, E 2012. Stormwater BMP treatment performance variability for sediment and heavy metals. Separation and Purification Technology, 84: 95-103.

Fletcher, T D, Shuster, W, Hunt, W F, Ashley, R, Butler, D, Arthur, S, Trowsdale, S, Barraud, S, Semadeni-Davies, A, Bertrand-Krajewski, J, Mikkelsen, P S, Rivard, G, Uhl, M, Dagenais, D \& Viklander, M 2015. SUDS, LID, BMPs, WSUD and more - The evolution and application of terminology surrounding urban drainage. Urban Water Journal, 12(7): 525-542.

Geberemarium, T K 2017. Post construction green infrastructure performance monitoring parameters and their functional components. Environments, 4(2): 1-11.

HR Wallingford Ltd 2017. Green approaches in river engineering: Supporting implementation of Green Infrastructure. Wallingford, UK: HR Wallingford Ltd. International Stormwater BMP Database (Version 2016 11 17) 2016. Available at: www.bmpdatabase.org [accessed on 8 September 2017]. 
Kazemi, F, Beecham, S \& Gibbs, J 2011. Streetscape biodiversity and the role of Bio-retention structure swales in an Australian urban environment. Landscape and Urban Planning, 101: 139-148.

Kondo, M C, Low, S C, Henning, J \& Branas, C C 2015.

The impact of green stormwater infrastructure installation on surrounding health and safety.

American Journal of Public Health, 105(3): 114-121.

Milandri, S G, Winter, K J, Chimphango, S B M, Armitage, N P, Mbui, D N, Jackson, G E, \& Liebau, V 2012. The performance of plant species in removing nutrients from stormwater in biofiltration systems in Cape Town. Water SA, 38(5): 655-662.

Mogens, H, Van Loosdrecht, M C M, Ekama, G A \& Brdjanovic, D 2008. Wastewater treatment development. In Mogens, H, Van Loosdrecht, M C M Ekama, G A \& Brdjanovic, D (Eds). Biological Wastewater Treatment Principles, Modelling and Design Biological Wastewater Treatment. London: IWA Publishing.

Quibell, G, Pegram, G C, Moolman, J, Matji, M P, Hohls, B \& Gorgens, A H M 2003. Development of a nonpoint source assessment guide: Test case studies. WRC Report No 696/2/03. Pretoria: Water Research Commission.

Schoeman, A M, Mackay, H M \& Stephenson, D 2001. A synthesis of South African urban runoff studies with special emphasis on runoff from high-density settlements. WRC Report No 598/1/01. Pretoria: Water Research Commission.
SEMCOG 2008. Low impact development manual for Michigan. Available at: www.semcog.org [accessed on 28 July 2017].

TRCA (Toronto and Region Conservation Authority), CVC (Credit Valley Conservation Authority) 2010. Low impact development stormwater management planning and design guide. Version 1. Ontario, Canada: TRCA. Available at: www.creditvalleyca. ca [accessed on 26 July 2017).

UN Water 2018. The United Nations World Water Development Report 2018: Nature-based solutions for water. Paris: UNESCO.

USEPA (US Environmental Protection Agency) n.d. Green Infrastructure. Washington, DC: US EPA. Available at: www.epa.gov/green-infrastructure. USEPA (US Environmental Protection Agency) 2009. Green roofs for stormwater runoff control. EPA Report No EPA/600/R-09/026. Cincinnati, OH: US EPA.

USEPA (US Environmental Protection Agency) 2012.

City of Camden Green Infrastructure Design Handbook. Integrating stormwater management into sustainable urban design. Green Infrastructure Technical Assistance Program: Cooper's Ferry Partnership. EPA Report No 830-R-13-008, Camden, NJ: US EPA.

USEPA (US Environmental Protection Agency) 2014. Greening the Iron Arts District. Green Infrastructure Interventions for Reducing Combined Sewer Overflow (CSO) in the City of Scranton, PA. Green
Infrastructure Technical Assistance Program. EPA Report No 833-R-16-013. Scranton, PA: US EPA. USEPA (US Environmental Protection Agency) 2016. What is Nonpoint Source? Washington, DC: US EPA. Available at: www.epa.gov/ green-infrastructure.

Wanielista, M P 1979. Stormwater Management: Quantity and Quality. Ann Arbor, MI: Ann Arbor Science Publishers.

Watershed Management Group 2012. Green Infrastructure for Southwestern neighbourhoods. Tucson, AZ: Watershed Management Group. Wisconsin Department of Natural Resources (DNR) 2003. Rain gardens: A how-to manual for homeowners. Madison, WI: DNR Publications. Wright Water Engineers Inc and Geosyntec Consultants Inc 2016. International Stormwater Best Managment Practices (BMP) Database. User's guide for BMP data entry spreadsheets, Version 3.3. Available at: www.bmpdatabase.org [accessed on 9 September 2017].

Xiao, Q \& Mcpherson, E G 2011. Performance of engineered soil and trees in a parking lot bioswale. Urban Water Journal, 8(4): 241-253.

Yang, B, Li, S, Wall, H A, Blackmore, P \& Wang, Z 2015. Green Infrastructure design for improving stormwater quality: Daybreak community in the United States West. Landscape Architecture Frontiers, 3(4): 12-21. 